\title{
ASSESSMENT OF LEAF MINER Liriomyza spp (DIPTERA: AGROMYZIDAE) DAMAGE ON TOMATO AND THE YIELD OUTPUT IN ILORIN, SOUTHERN GUINEA SAVANNAH, NIGERIA
}

\author{
${ }^{*}$ Mustapha, S., Musa, A.K. and Aliyu, A.S. \\ Department of Crop Protection, University of llorin, Ilorin, Kwara State, Nigeria \\ "Corresponding author's email: juniorsuleiman78@gmail.com
}

\begin{abstract}
Tomato plays an important nutritional role in human diet. Although, Nigeria is the largest producers of tomato in Africa, its production is threatened by the invasive polyphagous insect pest belonging to the genus Liriomyza. An experiment was conducted to enumerate the level of damage of the agromyzid fly Liriomyza spp on the tomato variety, UC82B. Infestations were observed on potted tomato plants and studied from December 2016 to March, 2017. The experimental treatment consisted of both screen house and field trials. The experiment was laid out in a Randomized Complete Block Design with four replicates. Data were collected on the number of tomato leaves mined by larvae of the pest every week after transplanting (WAT) and on the total weight of tomato fruits harvested. Using t-test statistical analysis, results revealed that tomato plants grown in the field were the most infested by the insect pest from 5 to 10 WAT having significantly higher $(P<0.05)$ mean population of the pest when compared to the screen house which had little or no infestation. However, there was no significant difference in the leaf damage by Liriomyza spp from 2 to 4 WAT. Tomato fruits harvested at the end of the experiment were weighed and observation showed that the screen house gave more fruit yield $(90.80 \pm 6.10 \mathrm{~g})$ compared to the field experiment $(24.20 \pm 2.27 \mathrm{~g})$ which was significantly lower due to leaf miner flies' damage on tomato leaves. Therefore, appropriate control measures of the insect pest are recommended where screen houses may not be accessible.
\end{abstract}

Keywords: leaf miner fly, Liriomyza spp., tomato leaves, infestation, damage, screen house, field, tomato fruit. 


\section{INTRODUCTION}

Nigeria has the largest amount of land harvested for fresh tomato in Africa with over 541,800 hectares which is followed by Egypt having over 214,016 ha (Etebu and Enaregha, 2013). Nigeria still remains the biggest producer of tomato in Africa (Borisade et al., 2017). Subsistence farmers cultivating 0.5 to 4 hectares of land accounts for about $90 \%$ of tomato supplies, while the remaining $10 \%$ is produced by large-scale or commercial producers (FAO, 2014). Tomato fruit can be cooked, eaten raw as salad or used as a condiment in food. It is used to produce juice, puree, sauce, ketchup and tomato paste. It is extensively used in the canning industry. Ripe tomato fruits are sometimes preserved traditionally by sun drying them (Abolusoro et al., 2014). Unfortunately, with all their benefits, huge amount of the crop is lost annually due to pest, post-harvest losses, poor handling and lack of good processing and modern storage facilities (Gebremariamd, 2015). The production is affected with many biotic and abiotic stresses such as diseases, insect pests and nematodes causing the reduction of tomato yield (Sanda et al., 2018). In the Southern Guinea Savanah of Nigeria, tomato has been observed to be plagued by the agromyzid leaf miner flies known as Liriomyza spp. This dipteran family Agromyzidae is a distinguished group of small, morphologically similar flies composing of about 1,800 species worldwide, with $75 \%$ of them producing mines in leaves (Bader, 2006). It is a polyphagous pest, infesting many host plants including horticultural crops and weeds. The leaf-mining flies are a diverse group of flies whose larvae feed internally in tomato leaves (Rauf et al., 2000). They cause damage by puncturing the leaf surface where larvae of flies proceed to feed on the tissue (DEFRA, 2007). Adult females cause damage of the mesophyll cells of host plant due to ovipositor probing (Lopez et al., 2010) to lay eggs. When eggs are hatched, the larvae begin to tunnel within the leaf tissue forming damaging and disfiguring mines usually serpentine in nature. Leaf mines reduce the quality of crops in addition to reducing the photosynthetic capability of the plant (DEFRA, 2007) and causing tissue death (Lopez et al., 2010). Despite the economic importance of leaf miner in tomato production, there are limited information available regarding its population dynamics and damages (Lopez et al., 2010) in the North Central of Nigeria. Therefore, a study on the damage levels in the most popularly grown tomato variety (UC82B) in Nigeria was conducted in order to develop future Integrated Pest Management (IPM) practices based on threshold damage levels (Lopez et al., 2010) for tomato.

\section{METHODOLOGY}

\section{Sites Description}

The field experiment was conducted at the Department of Agronomy pavilion while the screen house experiment was conducted at the Department of Crop Protection Screen house, Faculty of Agriculture, University of llorin. Ilorin is located in the Southern Guinea Savannah zone of Nigeria (4030' East and 8०26' North) (Omisore and Takim, 2013). 


\section{Micro climatic condition of the experiment}

The period of the experiment was from December 2016 to March, 2017 during the dry season. In December, the average humidity experienced in the study location was $24.57 \%$ which declined to $21.75 \%$ in January and gradually rose to $25.76 \%$ in March The lowest mean temperature recorded was in the month of January at $19.81^{\circ} \mathrm{C}$, while the highest max temperature experienced was at mean $37.61^{\circ} \mathrm{C}$ in March.

\section{Planting}

The study was carried out using potted plants laid out in a Randomized Complete Block Design (RCBD) with four replicates to determine leaf miner flies' infestation and damage on the tomato variety, UC82B. Tomato seeds were planted in seed trays (Ogoke et al., 2015) in the screen house in the Department of Agronomy to screen out pest from emerging seedlings before data collection. Seedlings were transplanted at four weeks after sowing into 7 litre pots with a diameter of $25 \mathrm{~cm}$ and height $23 \mathrm{~cm}$ for both the field and screen house experiment at the rate of one seedling per pot. Plot spacing for both the screen house and open field was a flatbed in a spacing of 240 by $150 \mathrm{~cm}\left(3.6 \mathrm{~m}^{2}\right)$ per replicate with an inter-bed spacing of one metre $(1 \mathrm{~m})$ and pots were arranged 50 by $80 \mathrm{~cm}$ having 12 pots per replicate. The surrounding secondary vegetation was cleared with cutlasses and hoes and the debris removed from the site (Ojiako et al., 2018). All other agronomic practises such as fertilization (NPK 15:15:15), watering, weeding and staking were carried out. Major pest like whiteflies were supressed in both the screen house and the open field by mixing $250 \mathrm{ml}$ of liquid soap in 2 litres of water in a pressure sprayer and spraying the underside of tomato leaves once every week from 2WAT to 7WAT.

\section{Identification of leaf miner flies and damage}

Leaves with mine tracks having visible brown pupa casing in between sheet of leaves were cut with a pair of scissors and placed in a container covered with muslin cloth for ventilation which was incubated at room temperature to allow development and emergence of adult flies for identification at genus level using classical morphological keys in the Department of Crop Protection Laboratory, University of llorin. Data collection began two weeks after transplanting and data were collected every week. Nine (9) tomato plants were selected at random from each replicate and data were collected for the damage caused by Liriomyza spp by counting the numbers of leaves infested per plant weekly. Leaf damage was observed as having serpentine mine tracks (Lopez et al., 2010) with trails of black frass on them.

\section{Weight of Tomato Fruit}

Harvesting of fruit began at 10 weeks after transplanting from both the screen house and the open field. Fruits harvested were put inside transparent nylon bags, labelled accordingly and taken to the laboratory for weighing using a weighing scale calibrated in grams. 


\section{Data Analysis}

Data collected on the total number of tomato leaves mined per plant and tomato fruit weight were represented in mean \pm standard error of mean. The data were thereafter subjected to independent-samples t-test with the $p$ value set at 0.05 using statistical package for social science version 20 .

\section{RESULTS}

\section{Leaf Damage Caused by Leaf Miner Flies}

Table 1 shows that infestation of leaf miner flies, Liriomyza spp started at 2WAT on tomato plants grown on the field with the mean leaf number of $4.00( \pm 1.68)$ affected which was not significantly different $(\mathrm{t}(6)=2.376, p=0.098)$ from the screen house experiment at both $2 \mathrm{WAT}$, 3 WAT $(4.50 \pm 1.84)$ and 4 WAT $(0.50 \pm 0.28)$. The mean numbers of leaves affected by Liriomyza spp further increased to $14.00( \pm 4.02)$ in 5WAT, $47.50( \pm 13.58)$ in 6WAT, $160.00( \pm 40.35)$ in 7WAT and again reduced to $121.00( \pm 27.57)$ in 8WAT, $59.80( \pm 11.46)$ in 9WAT and 30.00 $( \pm 8.89)$ in 10WAT. Table 1 also shows that the mean numbers of leaves mined reached its peak at 7 WAT $(160.00 \pm 40.35)$ on the field experiment which not only had the highest number of leaves damaged by Liriomyza spp, but was also highly significantly different $(t(6)=3.952, p$ $=0.029)$ from the screen house experiment with only $1.00( \pm 0.75)$ mean number of leaves mined.

\section{Total Weight of Tomato Fruits Harvested}

Table 2 shows the total harvested weight of tomato fruits from both the field and screen house experiment. Tomatoes grown out in the field gave a total harvested yield of $24.20( \pm 2.27) \mathrm{g}$ which was significantly $(t(6)=-10.232, p=0.001)$ lower than the yield of tomatoes $(90.80 \pm 6.10$ g) harvested from the screen house.

\section{Leaf Damage Caused by Liriomyza spp}

Plate 1 shows the unique serpentine print marks caused by the larvae of the dipterous flies. Mining print marks were observed on tomato leaves as white serpentine tracks, usually with continuous or broken trails of black frass as seen in Plate 1. Plate 2 also shows the after effect of mined leaves- the destruction of the mesophyll due to mining activities by the insect pest

\section{DISCUSSION}

The damage incurred from the presence of leaf miner flies on tomato plants was caused by internal mining of larvae in leaves (EPPO, 2005; DEFRA, 2007; Mujica et al., 2016). Mined marks on leaves reduced the level of photosynthesis in the crop (Capinera, 2008; Mujica et al., 2016) and also destroyed leaf mesophyll allowing pathogenic fungi to enter the leaf via feeding holes (Mujica et al., 2016) which eventually led to leaf drop. Also, leaves mined were often seen as dead or brown areas on leaf surface (Resh and Carde, 2009). Damages caused by adult 
females during the feeding and oviposition processes resulted in a stippled appearance on foliage, especially at the lead tip and along the leaf margins as described by Mujica et al. (2016). Throughout the experiment, the screen house prevented flies from gaining access to tomato leaves, thus experiencing the least amount of leaf miners' infestation on tomato as it was intended to screen out pests and serve as control. The lower yield obtained from the field experiment may be attributed to the leaf damages caused by the Agromyzid leaf miners, Liriomyza spp. 
Table 1: Leaf damage caused by leaf miner flies, Liriomyza spp. on tomato

\begin{tabular}{llllllllll}
\hline \multicolumn{7}{c}{ Weeks after transplanting (WAT) } \\
\hline Experiment & 2 & 3 & 4 & 5 & 6 & 7 & 8 & 9 & 10 \\
Field & $4.00 \pm 1.68$ & $4.50 \pm 1.84$ & $0.50 \pm 0.28$ & $14.00 \pm 4.02$ & $47.50 \pm 13.58$ & $160.00 \pm 40.35$ & $121.00 \pm 27.57$ & $59.80 \pm 11.46$ & $30.00 \pm 8.89$ \\
& & & & & & & & & \\
$\begin{array}{l}\text { Screen } \\
\text { house }\end{array}$ & $0.00 \pm 0.00$ & $0.00 \pm 0.00$ & $0.00 \pm 0.00$ & $0.00 \pm 0.00$ & $0.00 \pm 0.00$ & $1.00 \pm 0.75$ & $2.00 \pm 0.64$ & $1.50 \pm 0.50$ & $4.50 \pm 0.64$ \\
$\begin{array}{l}\text { T-value } \\
\text { P-value }\end{array}$ & 2.376 & 2.435 & 1.732 & 3.482 & 3.498 & 3.952 & 4.306 & 5.077 & 2.858 \\
& $0.098(\mathrm{NS})$ & $0.093(\mathrm{NS})$ & $0.182(\mathrm{NS})$ & 0.040 & 0.040 & 0.029 & 0.023 & 0.015 & 0.029 \\
\hline
\end{tabular}

Note: $P$-value is set at $0.05 ;$ NS = Not significance

Table 2: Total mean weight of tomato fruit harvested

\begin{tabular}{ll}
\hline Experiment & Weight of fruit $\mathbf{( g )}$ \\
\hline Field & $24.20 \pm 2.27$ \\
Screen house & $90.80 \pm 6.10$ \\
T-value & -10.232 \\
P-value & 0.001 \\
\hline
\end{tabular}

Note: P-value is set at 0.05 

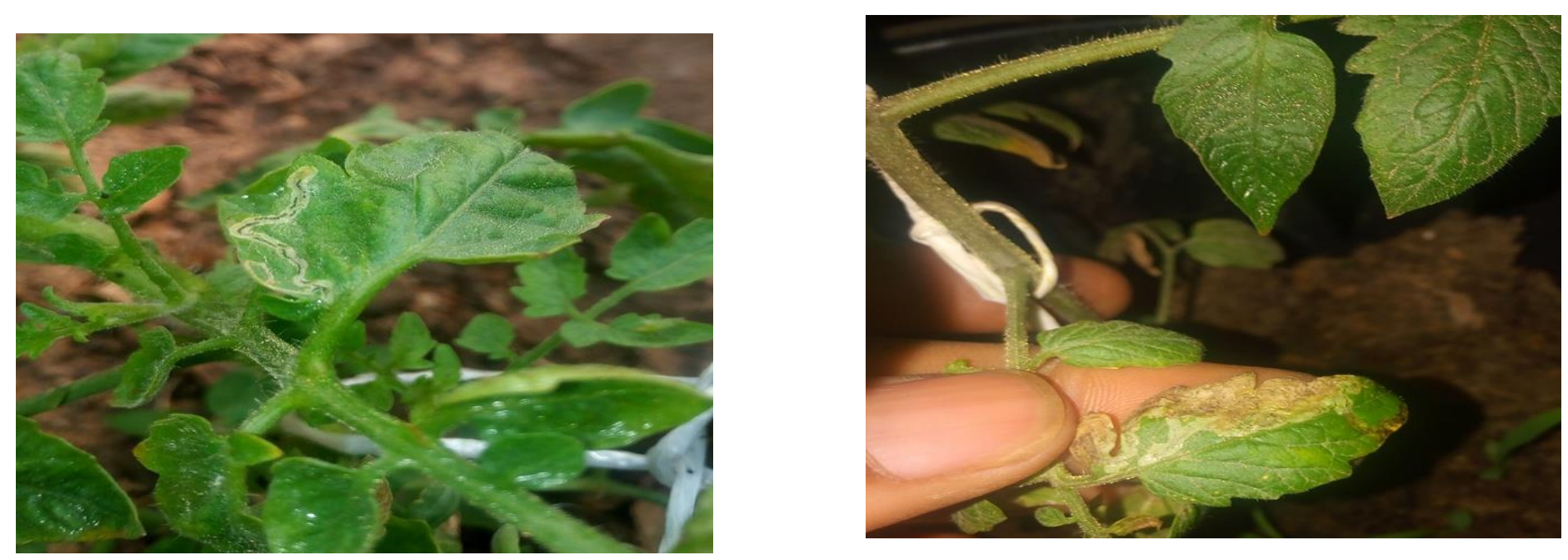

Plate 1: Larvae mining damage on tomato with Plate 2: leaf mesophyll destroyed by trails of black frass mining activity 


\section{CONCLUSION AND RECOMMENDATIONS}

The significant level of damage caused by the dipterous leaf miner Liriomyza spp has been shown in this study. Tomato grown in the field that had suffered severe attack by the leaf miner flies produced fewer fruit yield when compared to the yield of tomatoes grown in the screen house. It is advised that proper management procedures should be taken against such pest on tomato plants to boost yield in the study area thereby bringing in more financial returns. Although, chemicals can be used as a control measure against this pest, the practice is not a sustainable management technique. Therefore, there is further need to explore other methods of control that are less damaging to the environment to supress the population of the polyphagous insect Liriomyza spp in large scale agriculture.

\section{Conflict of Interest Statement}

The authors declare that they have no conflict of interest.

\section{REFERENCES}

Abolusoro, P. F., Ogunjimi, S.I. \& Abulosoro, S. A. (2014). Farmers' perception of the strategies for increasing tomato production in Kabba-Bunu Local Government Area of Kogi State, Nigeria. Agrosearch,14(2), 144-153.

Bader, A. E. (2006). Impact of interspecific interactions among parasitoids on inoculative biological control of leafminers attacking chrysanthemum, PhD Dissertation, Texas A and M University, College Station, Texas.

Borisade, O. A. L., Kolawole, A. O., Adebo, G. M., \& Uwaidem, Y. I. (2017). The tomato leafminer (Tuta absoluta) (Lepidoptera: Gelechiidae) attack in Nigeria: Effect of climate change on over-sighted pest or agro-bioterrorism. Journal of Agricultural Extension and Rural Development; 9(8), 163-171.

Capinera, J. L. (2008). Encyclopedia of Entomology (Vol. iv). Gainesville, USA: Springer Science+Business Media B.V.

DEFRA (Department for Environment Food and Rural Affairs). (2007). Liriomyza leaf miners. Retrieved from www.defra.gov.uk/planth/ph.html on September 21, 2019

EPPO (European and Mediterranean Plant Protection Organization). (2005). Liriomyza spp. Pm 7/53(1). EPPO Bulletin, 35, 335-344

Etebu, E., \& Enaregha, E. (2013). Postharvest quality of commercial tomato (Lycopersicon esculentum Mill.) fruits brought into Yenagoa Metropolis from Northern Nigeria. Journal of Biology and Agric Healthcare, 3(11), 2224-3208.

FAO (Food and Agriculture Organization of the United Nations) (2014). FAOSTAT. Retrieved from http://faostat3.fao.org/faostatgateway/go/to/download/Q/QC/E on September 19th 2019 
Gebremariamd, G. (2015). Tuta absoluta, A global looming challenge in tomato production, Review paper. Journal of Biology and Agric Healthcare, 5(14), 57-62.

López, R., Carmona, D., Vincini, A. M., Monterubbianesi, G., \& Caldiz, D. (2010). Pest Management Population Dynamics and Damage Caused by the Leafminer Liriomyza huidobrensis Blanchard (Diptera: Agromyzidae), on Seven Potato Processing Varieties Grown in Temperate Environment. Neotropical Entomology, 39(1), 108-114.

Mujica, N., Khadioli, N., Le Ru, B., Ong'amo, G., \& Carhuapoma, P. (2016). American serpentine leafminer, Liriomyza trifolii (Burgess, 1880). In: Kroschel, J., Mujica, N., Carhuapoma, P., Sporleder, M. (eds.). Pest distribution and risk atlas for Africa. Potential global and regional distribution and abundance of agricultural and horticultural pests and associated bio-control agents under current and future climates. Lima (Peru). International Potato Centre (CIP). ISBN 978-92-9060-476-1.

Ogoke, I. J., Ike, G. A., Echereobia, C. O. \& Ngwuta, A. A. (2015). Non-destructive leaf area determination in African eggplant (Solanum macrocarpon). Agrosearch, 15 (2), 1320 .

Ojiako, F.O., Ibe, A. E., Ogu, E. C. \& Okonkwo, C. C. (2018). Effect of Varieties and Mulch types on foliar insect pests of Okra (Abelmoschus esculentus L. (Moench)) in a humid tropical environment. Agrosearch, 18 (2), 38-56.

Omisore, J. K. \& Takim, F. O. (2013). Effect of weed removal and plant population on weed suppression and performance of maize (Zea mays L.) in the Southern Guinea Savanna of Nigeria. Centrepoint Journal (Science edition), 19 (1), 69-80.

Rauf, A., Shepard, B. M. \& Johnson, M. W. (2000). Leafminers in vegetables, ornamental plants and weeds in Indonesia: surveys of host crops, species composition and parasitoids. International Journal of Pest Management, 46, 257-266.

Resh, V. H., \& Carde, R. T. (2009). Encyclopedia of INSECTS (2nd ed.). California: Elsevier, Inc.

Sanda, N. B., Sunusi, M., Hamisu, H. S., Wudil, B. S., Sule, H. \& Abdullahi, A. M. (2018). Biological Invasion of Tomato Leaf Miner, Tuta absoluta (Meyrick) in Nigeria: Problems and Management Strategies Optimization: A Review. Asian Journal of Agricultural and Horticultural Research, 1(4), 1-14. 